\title{
Effects of sheep kraal manure on growth, dry matter yield and leaf nutrient composition of a local Amaranthus accession in the central region of the Eastern Cape Province, South Africa ${ }^{\#}$
}

\author{
S Mhlontlo, P Muchaonyerwa and PNS Mnkeni* \\ Department of Agronomy, Faculty of Science and Agriculture, University of Fort Hare, Private Bag X314, Alice 5700, South Africa
}

\begin{abstract}
Indigenous vegetables that supply abundant amounts of protein, vitamins, calories and minerals could alleviate problems of malnutrition, in developing countries. Amaranthus is one such vegetable that could be domesticated and cultivated but information on its fertility requirements is scanty. A dry-land field experiment was therefore conducted to study the effects of sheep kraal manure application rates on growth, fresh and dry matter yields, nutrient uptake and grain yield of one of the Amaranthus accessions that grow in the wild in the Eastern Cape. The treatments were sheep kraal manure rates ranging from 0 to $10 \mathrm{t} / \mathrm{ha}$ and an NPK $\{2: 3: 4(30)+0.5 \% \mathrm{Zn}\}$ fertiliser as a positive control at $150 \mathrm{~kg} / \mathrm{ha}$. Low manure rates $(\leq 2.5 \mathrm{t} / \mathrm{ha})$ resulted in plant heights and fresh matter yields which were comparable to those in the unfertilised control, whereas higher rates ( 5 and $10 \mathrm{t} / \mathrm{ha}$ ) and NPK fertiliser gave greater plant heights and higher yields at both 30 and 60 days after transplant (DAT) $(\mathrm{p}<0.05)$. At 30 DAT, manure application rates of $\geq 2.5 \mathrm{t} / \mathrm{ha}$ and the NPK fertiliser treatment, produced greater shoot dry-matter yields ( $\geq 29.35 \mathrm{~g} /$ plant) than the unfertilised control ( $17.11 \mathrm{~g} / \mathrm{plant})$. Uptake of $\mathrm{N}$ and $\mathrm{P}$ in the leaves increased with increase in manure application rate with $\mathrm{N}$ uptake reaching a maximum of $308 \mathrm{mg} \mathrm{N} / \mathrm{plant}$ at a manure rate of $2.5 \mathrm{t} / \mathrm{ha}$ which corresponded with the maximum dry matter yield of $45.97 \mathrm{~g} / \mathrm{plant}$. There was no effect of manure rate or fertiliser on residual soil $\mathrm{N}$ and $\mathrm{Ca}$, whereas $\mathrm{P}, \mathrm{K}, \mathrm{Mg}$ and $\mathrm{Zn}$ were increased $(\mathrm{p}<0.005)$. The findings suggested that $\geq 2.5 \mathrm{t} / \mathrm{ha}$ sheep kraal manure could result in growth, nutrient uptake and yield comparable to $150 \mathrm{~kg} / \mathrm{ha}$ NPK fertiliser for the Amaranthus accession used in this work
\end{abstract}

Keywords: Amaranthus accession, sheep manure, dry matter yield, nutrient composition, residual nutrients

\section{Introduction}

Hunger and malnutrition are mostly experienced in developing countries where they affect growth and development of children (Aphane et al., 2003). Foods of animal origin, which are major sources of vitamins and proteins, are often too expensive for poor households (Aphane et al., 2003; Wehmeyer and Rose, 1983). Vegetables that supply abundant amounts of protein, vitamins, calories and minerals, needed in a diet, could alleviate problems associated with malnutrition (Wehmeyer and Rose, 1983). However, the production of exotic vegetables is made difficult by harsh climatic and resource-poor conditions encountered in most rural areas, where problems of malnutrition occur.

More than 100 different indigenous species, including Amaranthus sp., Corchorus genera, Cleome gynandra, grow well in such areas (Jansen van Rensburg et al., 2004; Aphane et al., 2003). They are popular in communities such as in the former Transkei, South Africa, where their leaves are gathered from plants growing in the wild, chopped and mixed with maize meal to prepare a traditional meal known as 'imifino' or 'isigwampa' (Wehmeyer and Rose, 1983). Amaranthus could be cultivated in areas of Southern Africa where there is inadequate or unreliable rainfall (Jansen Van Rensburg et al., 2004) but information

\footnotetext{
Revised version. Originally presented at the International Symposium on the Nutritional Value and Water Use of Indigenous Crops for Improved Livelihoods held on 19 and 20 September 2006 at the University of Pretoria in Pretoria, South Africa

* To whom all correspondence should be addressed.

邑 +2740 602 2139; fax: +2740 653 1730; e-mail:pmnkeni@ufh.ac.za
}

on its fertilisation requirements is limited (Elbehri et al., 1993). Moreover chemical fertilisers are expensive for the resourcepoor farmers who often utilise those vegetables (Jansen Van Rensburg et al., 2004). Hence there is need to investigate cheaper sources of nutrients such as animal manures. According to Schippers (2000), the crop gives good yield when high levels of nitrogen are applied and it responds well to organic matter.

Farmers in the Eastern Cape use kraal manure in their maize-based cropping systems to address problems of declining soil fertility (Van Averbeke and De Lange, 1995). While guidelines exist on the use of kraal manure for crops such as maize (Van Averbeke and Yoganathan, 1997), no information could be found on the use of kraal manure on Amaranthus in the Eastern Cape. This article reports on effects of sheep kraal manure application rates on growth, fresh and dry matter yields, nutrient uptake and grain yield of a local Amaranthus accession in the central region of the Eastern Cape.

\section{Experimental}

The experiment was conducted between November 2002 and May 2003 in Gqumahashe village ( $32^{\circ} 45^{\prime}$ S; $26^{\circ} 52^{\prime} \mathrm{E}$ ), five $\mathrm{km}$ north of Alice town. The soil contained $0.026 \% \mathrm{~K}, 0.35 \%$ $\mathrm{Ca}, 0.044 \% \mathrm{Mg}, 2.5 \mathrm{mg} \mathrm{P} / \ell$ and $1.4 \mathrm{mg} \mathrm{Zn} / \ell$, with $\mathrm{pH} 5.3$ (in $\mathrm{KCl})$. Sheep kraal manure used in this study was collected from kraals in the village and contained $1.8 \% \mathrm{~N}, 3.7 \% \mathrm{Ca}$, $1.4 \% \mathrm{Mg}, 0.37 \% \mathrm{P}, 16000 \mathrm{mg} / \mathrm{kg}$ Fe and $872 \mathrm{mg} / \mathrm{kg} \mathrm{Zn}$. It was applied to the soil at different rates $(0,0.3,0.6,1.2,2.5,5.0$ and $10 \mathrm{t} / \mathrm{ha}$ ). Inorganic NPK fertiliser $\{2: 3: 4(30)+0.5 \% \mathrm{Zn}\}$ was applied at a rate of $150 \mathrm{~kg} / \mathrm{ha}$, the rate recommended for spinach by Makus (1984), as a positive control. The experiment 
was arranged in a randomised complete block design (RCBD) with four replications. Sheep kraal manure was broadcast in the designated plots after land preparation and incorporated into the soil, using a rotavator, two weeks before transplanting. Inorganic fertiliser was also applied by broadcasting and incorporated a day before planting.

One-month-old seedlings of an unclassified Amaranthus accession that grows in the wild in the Eastern Cape were transplanted on 17 December 2002, in 6 m rows (6 rows /plot) with an inter-row spacing of $1 \mathrm{~m}$ and intra-row spacing of $30 \mathrm{~cm}$. The seedlings were then irrigated for the first week to aid establishment, whereafter they solely depended on rain. Other management practices, like weeding, were the same across the treatments. No pesticides were applied. Data collection and sampling for growth, fresh and dry matter yields, were done at 30 and $60 \mathrm{~d}$ after transplanting (DAT). Two plants were randomly selected from the two middle rows in each plot and uprooted. Stem girth, plant height, number of leaves and fresh mass (stems and leaves) were determined, before dry matter (leaves and stems) was determined after drying in an oven at $60^{\circ} \mathrm{C}$ to constant mass. All oven-dried leaf samples were ground, digested and analysed for total $\mathrm{N}$, $\mathrm{P}, \mathrm{K}, \mathrm{Ca}, \mathrm{Mg}, \mathrm{Fe}$ and $\mathrm{Zn}$ as described by Okalebo et al. (2002). Nutrient uptake (N, P, K, Ca, Mg, Fe and Zn) was then calculated from the leaf dry matter and the composition of the nutrients in the leaves. Grain mass and residual soil nutrient composition were determined at 90 DAT. Analysis of variance (ANOVA) was done using the MStat C statistical software and least significant differences (LSD) at $5 \%$ significant level were used to separate the means.

\section{Results and discussion}

\section{Effects of sheep manure application rate on growth of Amaranthus}

Plant height, number of leaves and stem girth, increased significantly $(\mathrm{p}<0.05)$ with an increase in sheep kraal manure application rate (Table 1). At low manure rates $(\leq 2.5 \mathrm{t} / \mathrm{ha})$, the plants had comparable height to those in the unfertilised control, whereas higher rates (5 and $10 \mathrm{t} / \mathrm{ha}$ ) and NPK fertiliser resulted in greater plant heights both at 30 and 60 DAT. Similar results were observed by Elbehri et al. (1993), who reported increased Amaranthus plant height at higher nitrogen application rate. At low manure rates $(\leq 1.3 \mathrm{t} / \mathrm{ha})$ the number of leaves were comparable to the unfertilised control, whereas higher rates (2.5 to
$10 \mathrm{t} / \mathrm{ha}$ ) and the NPK fertiliser treatments produced larger numbers of leaves both at 30 and 60 DAT. These responses could be ascribed to increased uptake of nutrients as a result of the availability of larger amounts of nutrients in the soil as the amount of manure increased.

Manure application resulted in larger stem girth when compared to the unfertilised control but there was no additional response to increased application from 0.3 to $10 \mathrm{t} / \mathrm{ha}$, giving values similar to that obtained with the NPK fertiliser. These results appear to indicate that addition of manure at $0.3 \mathrm{t} / \mathrm{ha}$ provided sufficient nutrients for maximum stem girth at growth stages up to $60 \mathrm{DAT}$ and the rest of the nutrients were partitioned towards stem elongation and leaf production.

\section{Sheep manure application effects on fresh yield of Amaranthus}

Fresh matter yield (leaf, stem and shoot) increased significantly $(\mathrm{p}<0.05)$ with an increase in sheep kraal manure application rate (Table 2). Where low rates of kraal manure $(\leq 2.5 \mathrm{t} / \mathrm{ha}$ ) were applied, leaf stem and shoot fresh matter yields were comparable to unfertilised control both at 30 and 60 DAT. Higher rates of sheep kraal manure (5 and $10 \mathrm{t} / \mathrm{ha}$ ) produced higher fresh matter yields than the unfertilised control, giving values similar to that obtained with the NPK fertiliser. At the higher sheep kraal manure application rates, the results compared well with those reported by Makus (1984) for different accessions of Amaranthus, fertilised with mineral fertiliser at recommended rates for spinach. The values obtained in the present study were lower than those reported by Allemann et al. (1996) for different varieties of Amaranthus at ARC-Roodeplaat, the research station of the Vegetable and Ornamental Plant Institute, near Pretoria. This is logical, since in the latter experiment the crop was grown under irrigation, while in the present study it was grown under rain-fed conditions in an abnormally dry season. In the irrigated experiment of Allemann et al. (1996) fertiliser applications were also much higher than in the present experiment, as is normal for irrigated conditions. In the present study the highest leaf fresh matter yield at 30 DAT was obtained with an application of $5 \mathrm{t} /$ ha sheep kraal manure, while at 60 DAT it was obtained with the inorganic NPK fertiliser treatment. These results indicate that a sheep kraal manure application rate of at least $5 \mathrm{t} / \mathrm{ha}$ is critical to maximise Amaranthus fresh matter yield if the crop is to be cultivated and used as a vegetable.

\begin{tabular}{|c|c|c|c|c|c|c|}
\hline \multicolumn{8}{|c|}{ TABLE 1 } \\
\hline \multirow{2}{*}{$\begin{array}{c}\text { Manure rates } \\
\text { (t/ha) }\end{array}$} & \multicolumn{2}{|c|}{ Plant height (cm) } & \multicolumn{2}{c|}{ Stem girth (cm) } & \multicolumn{2}{c|}{ Number of leaves } \\
\cline { 2 - 7 } & $\mathbf{3 0}$ DAT* $^{*}$ & $\mathbf{6 0}$ DAT & $\mathbf{3 0 ~ D A T}$ & $\mathbf{6 0}$ DAT & 30 DAT & 60 DAT \\
\hline 0 & $30.50 c^{* *}$ & $37.00 \mathrm{~d}$ & $0.75 \mathrm{c}$ & $1.40 \mathrm{~b}$ & $67 \mathrm{~b}$ & $92 \mathrm{c}$ \\
\hline 0.3 & $34.00 \mathrm{bc}$ & $42.25 \mathrm{~cd}$ & $1.00 \mathrm{bc}$ & $1.68 \mathrm{ab}$ & $86 \mathrm{ab}$ & $111 \mathrm{bc}$ \\
\hline 0.6 & $33.75 \mathrm{bc}$ & $41.50 \mathrm{~d}$ & $1.10 \mathrm{ab}$ & $1.70 \mathrm{ab}$ & $86 \mathrm{ab}$ & $112 \mathrm{bc}$ \\
\hline 1.3 & $38.75 \mathrm{abc}$ & $48.25 \mathrm{bcd}$ & $1.18 \mathrm{ab}$ & $1.73 \mathrm{a}$ & $99 \mathrm{ab}$ & $122 \mathrm{bc}$ \\
\hline 2.5 & $40.50 \mathrm{abc}$ & $47.75 \mathrm{bcd}$ & $1.25 \mathrm{ab}$ & $1.90 \mathrm{a}$ & $117 \mathrm{a}$ & $140 \mathrm{abc}$ \\
\hline 5.0 & $45.00 \mathrm{ab}$ & $54.25 \mathrm{abc}$ & $1.35 \mathrm{a}$ & $1.95 \mathrm{a}$ & $118 \mathrm{a}$ & $150 \mathrm{ab}$ \\
\hline 10.0 & $47.25 \mathrm{a}$ & $61.00 \mathrm{a}$ & $1.30 \mathrm{a}$ & $2.03 \mathrm{a}$ & $126 \mathrm{a}$ & $153 \mathrm{ab}$ \\
\hline NPK fertiliser & $46.50 \mathrm{a}$ & $57.50 \mathrm{ab}$ & $1.23 \mathrm{ab}$ & $2.03 \mathrm{a}$ & $114 \mathrm{ab}$ & $181 \mathrm{a}$ \\
\hline CV (\%) & 21 & 17 & 17 & 16 & 32 & 27 \\
\hline
\end{tabular}

*DAT = Days after transplanting

**Means in each column followed by the same letter or none at all are not significantly different at $p<0.05$. 


\begin{tabular}{|c|c|c|c|c|c|c|}
\hline \multicolumn{7}{|c|}{$\begin{array}{c}\text { TABLE } 2 \\
\text { Effects of sheep kraal manure application on fresh matter yield of Amaranthus }\end{array}$} \\
\hline \multirow[t]{2}{*}{$\begin{array}{l}\text { Manure rate } \\
\text { (t/ha) }\end{array}$} & \multicolumn{2}{|c|}{$\begin{array}{l}\text { Leaves } \\
\text { (g/plant) }\end{array}$} & \multicolumn{2}{|c|}{$\begin{array}{c}\text { Stems } \\
\text { (g/plant) }\end{array}$} & \multicolumn{2}{|c|}{$\begin{array}{c}\text { Shoots } \\
\text { (g/plant) }\end{array}$} \\
\hline & 30 DAT & 60 DAT & 30 DAT & 60 DAT & 30 DAT & 60 DAT \\
\hline 0 & $18.88 d^{*}$ & $28.50 \mathrm{c}$ & $21.73 d$ & 45.76d & $45.66 \mathrm{c}$ & $97.16 \mathrm{~d}$ \\
\hline 0.3 & $25.85 \mathrm{~cd}$ & 51.82bc & 31.39cd & 66.08cd & 67.47bc & $132.66 \mathrm{~cd}$ \\
\hline 0.6 & 31.08abcd & $56.05 \mathrm{bc}$ & 43.33bcd & 66.43cd & 96.14abc & 143.53cd \\
\hline 1.3 & 28.48bcd & $54.06 \mathrm{bc}$ & 43.93bcd & 96.90bcd & 103.27abc & 154.70bcd \\
\hline 2.5 & 38.90abcd & 68.21abc & 51.55abcd & 113.15abcd & 106.54abc & 194.85abc \\
\hline 5.0 & $50.45 a$ & 77.25ab & 78.00ab & 129.40abc & $149.17 a$ & 239.05ab \\
\hline 10.0 & 48.88ab & 78.73ab & $90.28 \mathrm{a}$ & $156.60 \mathrm{ab}$ & $149.72 \mathrm{a}$ & $262.45 a$ \\
\hline NPK fertiliser & 41.95abc & 104.10a & 70.28abc & 181.38a & 127.94ab & $258.80 a$ \\
\hline CV (\%) & 39 & 46 & 53 & 49 & 50 & 35 \\
\hline
\end{tabular}

\begin{tabular}{|c|c|c|c|c|c|c|c|}
\hline \multicolumn{8}{|c|}{$\begin{array}{c}\text { TABLE } 3 \\
\text { Effects of sheep kraal manure application rates on dry matter yield of Amaranthus }\end{array}$} \\
\hline \multirow[t]{2}{*}{$\begin{array}{l}\text { Manure rate } \\
\text { (t/ha) }\end{array}$} & \multicolumn{2}{|c|}{$\begin{array}{l}\text { Leaves } \\
\text { (g/plant) }\end{array}$} & \multicolumn{2}{|c|}{$\begin{array}{l}\text { Stems } \\
\text { (g/plant) }\end{array}$} & \multicolumn{2}{|c|}{$\begin{array}{l}\text { Shoots } \\
\text { (g/plant) }\end{array}$} & \multirow{2}{*}{$\begin{array}{c}\text { Grain } \\
\text { yield } \\
\text { (g/plot) }\end{array}$} \\
\hline & 30 DAT & 60 DAT & 30 DAT & 60 DAT & 30 DAT & 60 DAT & \\
\hline 0 & $6.17 c^{*}$ & $10.26 \mathrm{f}$ & $4.11 d$ & $5.69 \mathrm{~d}$ & 17.11c & $19.35 c$ & 362 \\
\hline 0.3 & $8.44 \mathrm{bc}$ & 14.62ef & $6.15 \mathrm{~cd}$ & 10.09cd & $21.88 \mathrm{bc}$ & $28.74 b$ & 402 \\
\hline 0.6 & 9.79abc & 16.63de & 7.55bcd & 12.65bcd & 26.67abc & $31.27 \mathrm{~b}$ & 405 \\
\hline 1.3 & 9.75abc & 18.32cde & 7.71bcd & 15.49bcd & 27.03abc & $36.69 b$ & 412 \\
\hline 2.5 & 11.84ab & 21.96bcd & 9.30abc & 18.28abc & 29.35ab & $45.97 \mathrm{a}$ & 428 \\
\hline 5.0 & 12.49ab & 23.52abc & 9.86abc & $22.28 \mathrm{ab}$ & $30.74 a b$ & $46.97 \mathrm{a}$ & 443 \\
\hline 10.0 & 13.44a & 24.68ab & $14.03 \mathrm{a}$ & $25.35 a$ & $37.68 \mathrm{a}$ & $49.77 \mathrm{a}$ & 488 \\
\hline NPK fertiliser & 12.16ab & $27.72 \mathrm{a}$ & 12.07ab & $26.49 a$ & $38.09 a$ & $52.78 a$ & 532 \\
\hline CV (\%) & 30 & 19 & 38 & 39 & 27 & 16 & 33 \\
\hline
\end{tabular}

* Means in each column followed by the same letter or none at all are not significantly different at $p<0.05$

\section{Effects of sheep manure rate on dry matter and grain yield of Amaranthus}

Dry matter (leaf, stem and shoot) yields increased with increasing manure application rate (Table 3). At 30 DAT, manure application rates of $\geq 2.5 \mathrm{t} / \mathrm{ha}$ and the NPK fertilised treatment, produced greater shoot dry-matter yields than the unfertilised control. The yields obtained in the present study were lower than those reported for the irrigated experiment by Allemann et al. (1996), which is logical. The unfertilised control produced yields which were comparable to those from manure rates ranging from 0.3 to $1.27 \mathrm{t} / \mathrm{ha}$. Elbehri et al. (1993) reported improved forage yield of Amaranthus as a result of nitrogen addition. The findings suggested that $2.5 \mathrm{t} / \mathrm{ha}$ of sheep kraal manure would supply sufficient nutrients (compared to the recommended fertiliser application) for dried vegetable Amaranthus, especially when the leaves are to be harvested at a young age (30 DAT). This is recommended and is practised in the Eastern Cape (Wehmeyer and Rose, 1983; Bhat and Rubuluza, 2002). This critical manure rate is lower than the one based on fresh matter yield. This could be a result of differences in water uptake by the plants at the time of sampling. From the differences in fresh and dry matter responses to the two different kraal manure rates, the results indicated that the plants in the $5 \mathrm{t} / \mathrm{ha}$ manure treatment took up more water than in the $2.5 \mathrm{t} / \mathrm{ha}$ treatment. Since fresh material is normally consumed, a kraal manure application of $5 \mathrm{t} /$ ha would seem the more logical rate at which to apply it. It is important to note that at the young growth stage at which the leaves are normally harvested (30 DAT) fairly moderate sheep kraal manure applications gave better results than inorganic NPK fertilisers. Grain yield did not respond to sheep kraal manure or fertiliser application when compared to the control (Table 3).

\section{Sheep manure effects on nutrient concentrations and amounts in Amaranthus leaves}

The concentrations of $\mathrm{Ca}, \mathrm{Mg}, \mathrm{P}, \mathrm{N}$ and $\mathrm{K}$ in the Amaranthus leaves agreed very well with those reported for different accessions of the crop by Makus (1984) while Fe and Zn were much lower. There were no effects of rate of manure application on $\mathrm{N}$, P, K, Ca, Mg, and Zn concentrations in Amaranthus leaves at 30 DAT (Table 4). These results agree with those of Ore-Oluwa et al. (1981) who reported no effects of nitrogen on accumulation of $\mathrm{Ca}, \mathrm{K}, \mathrm{Na}, \mathrm{Cu}$ and $\mathrm{Zn}$ in Amaranthus leaves. However, uptake of $\mathrm{N}$ and $\mathrm{P}$ in the leaves increased with increase in manure application rate, with $\mathrm{N}$ uptake reaching a maximum at a manure rate of $2.5 \mathrm{t} / \mathrm{ha}$, which corresponded with maximum dry matter yield (Table 5). Due to the close relation between $\mathrm{N}$ and protein, the same trend was observed for crude protein. Crude protein contents compared favourably with other indigenous vegetables used in the Eastern Cape, and thus could supplement the maizebased diets with protein (Wehmeyer and Rose, 1983). The findings indicate that $2.5 \mathrm{t} /$ ha or higher rates of sheep kraal manure supplied adequate amounts of nutrients (especially $\mathrm{N}$ and $\mathrm{P}$ ) for optimum yields.

Leaf Fe concentration results agreed with those reported by Jansen Van Rensburg et al. (2004). It varied with different 


\begin{tabular}{|c|c|c|c|c|c|c|c|}
\hline \multicolumn{8}{|c|}{$\begin{array}{c}\text { TABLE } 4 \\
\text { Effects of sheep kraal manure application on nutrient concentrations in } \\
\text { Amaranthus leaves at } 30 \text { DAT }\end{array}$} \\
\hline \multirow{3}{*}{$\begin{array}{l}\text { Manure rate } \\
(\mathrm{t} / \mathrm{ha})\end{array}$} & \multicolumn{7}{|c|}{ Nutrient concentrations in Amaranthus leaves } \\
\hline & $\mathbf{N}$ & $\mathbf{P}$ & $\mathrm{K}$ & Mg & $\mathrm{Ca}$ & $\mathrm{Fe}$ & $\mathrm{Zn}$ \\
\hline & \multicolumn{5}{|c|}{ (\%) } & \multicolumn{2}{|c|}{$(\mathrm{mg} / \mathrm{kg})$} \\
\hline 0 & $2.17 *$ & 0.09 & 3.3 & 1.4 & 3.9 & $60.0 \mathrm{bc}$ & 2.9 \\
\hline 0.3 & 2.19 & 0.12 & 3.5 & 1.4 & 3.9 & $46.9 \mathrm{c}$ & 3.2 \\
\hline 0.6 & 2.57 & 0.09 & 3.8 & 1.3 & 3.6 & 132.3a & 2.4 \\
\hline 1.3 & 2.34 & 0.12 & 3.4 & 1.3 & 3.8 & 90.9abc & 2.2 \\
\hline 2.5 & 2.53 & 0.12 & 3.6 & 1.5 & 3.7 & $100.6 a b c$ & 2.3 \\
\hline 5.0 & 2.13 & 0.11 & 3.7 & 1.3 & 3.5 & 81.1abc & 2.5 \\
\hline 10.0 & 2.25 & 0.13 & 4.3 & 1.5 & 3.7 & 97.8abc & 3.8 \\
\hline NPK fertiliser & 2.47 & 0.14 & 4.7 & 1.3 & 3.7 & $116.5 \mathrm{ab}$ & 2.3 \\
\hline CV (\%) & 17 & 14 & 16 & 13 & 12 & 43 & 49 \\
\hline
\end{tabular}

*Means in each column followed by the same letter or none at all are not significantly different at $p<0.05$.

\begin{tabular}{|c|c|c|c|c|c|c|}
\hline \multicolumn{7}{|c|}{$\begin{array}{c}\text { TABLE } 5 \\
\text { Effects of sheep kraal manure rate on nutrient amounts in Amaranthus } \\
\text { leaves at } 30 \text { DAT }\end{array}$} \\
\hline \multirow{2}{*}{$\begin{array}{l}\text { Manure rate } \\
\text { (t/ha) }\end{array}$} & \multicolumn{5}{|c|}{ Nutrient uptake (mg/plant) } & \multirow{2}{*}{$\begin{array}{c}\text { Crude } \\
\text { protein } \\
\text { (g/plant) }\end{array}$} \\
\hline & $\mathbf{N}$ & $\mathbf{P}$ & $\mathbf{K}$ & Mg & $\mathrm{Ca}$ & \\
\hline 0 & $134 \mathrm{c}$ & 6.03d & 207 & 82 & 240 & $0.84 \mathrm{c}$ \\
\hline 0.3 & 178bc & $9.05 \mathrm{~cd}$ & 288 & 116 & 324 & $1.11 \mathrm{bc}$ \\
\hline 0.6 & $264 a b$ & 9.88bcd & 360 & 138 & 352 & $1.65 \mathrm{ab}$ \\
\hline 1.3 & $262 \mathrm{ab}$ & 11.88abcd & 310 & 130 & 369 & $1.64 \mathrm{ab}$ \\
\hline 2.5 & $308 a$ & 13.10abc & 482 & 176 & 436 & $1.93 a$ \\
\hline 5.0 & 273ab & 13.38abc & 506 & 158 & 443 & 1.71ab \\
\hline 10.0 & $267 a b$ & 17.83a & 520 & 182 & 503 & $1.67 \mathrm{ab}$ \\
\hline NPK fertiliser & $315 a$ & $16.80 \mathrm{ab}$ & 565 & 154 & 452 & $1.97 \mathrm{a}$ \\
\hline CV (\%) & 35 & 35 & 34 & 34 & 34 & 21 \\
\hline
\end{tabular}

*Means in each column followed by the same letter or none at all are not significantly different at p $<0.05$

manure and fertiliser applications, though no specific trend was observed (Table 4). Rates of manure application greater than $0.6 \mathrm{t} / \mathrm{ha}$, however, generally resulted in levels of Fe that were higher than in the control treatment. Since Fe is an important element in human nutrition, these results suggest that in addition to improving yields, fertilisation of Amaranthus with sheep manure will have the added benefit of improving its nutritional value, including Fe.

\section{Effects of sheep manure application rates on residual soil nutrient composition}

Post cropping soil $\mathrm{pH}$ increased from 5.4 to 5.8 in response to increasing manure rate from 0 to $10 \mathrm{t} / \mathrm{ha}$, whereas the NPK fertiliser depressed it (Table 6). Manure rates $<2.5 \mathrm{t} / \mathrm{ha}$ had postcropping $\mathrm{pH}$ values which were comparable to the unfertilised control, whereas higher rates had significantly higher $\mathrm{pH}$ values $(p<0.05)$. The liming effect of manure could be of great significance in the Eastern Cape where manure is readily available and $\mathrm{pH}$ of most of the soils has been reported to be critically low (Mandiringana et al., 2005).

There was no effect of manure rate or fertiliser on residual soil $\mathrm{N}$, suggesting that the crop had exhausted the soil $\mathrm{N}$ from manure or fertiliser. Lower manure rates $(\leq 1.3 \mathrm{t} / \mathrm{ha})$ resulted in lower residual soil $P$ than the higher rates (2.5-10 $\mathrm{t} / \mathrm{ha}$ ). Although the latter gave lower plant-available soil $\mathrm{P}$ levels than the NPK fertiliser (Table 6), the increases were substantial, which agrees with the findings of Eghball and Power (1999), who reported an accumulation of soil P as a result of manure application. This could probably benefit the next crop grown on this soil but could over several seasons of application of high manure rates lead to the build-up of excessive soil $\mathrm{P}$ levels. This could eventually result in $\mathrm{P} /$ $\mathrm{Zn}$ imbalance, which could result in reduced $\mathrm{Zn}$ uptake if manure is applied at high levels over long periods (Brady and Weil, 1999).

Residual soil K from plots fertilised with NPK fertiliser, and low manure rates ( 0.3 to $1.3 \mathrm{t} / \mathrm{ha})$, did not differ statistically significantly from that in the unfertilised control. At higher kraal manure rates (2.5 to $10 \mathrm{t} / \mathrm{ha}$ ) sharp increases in soil $\mathrm{K}$ levels were observed. Soil $\mathrm{K}$ levels in all the treatments, even the unfertilised control, exceeded $200 \mathrm{mg} \mathrm{K} / \mathrm{kg}$. This is above the critical level of 80 to $120 \mathrm{mg} \mathrm{K} / \mathrm{kh}$ (Bornman et al., 1989), which explains the lack of $K$ uptake response to manure or fertiliser application. The results are in agreement with Laker (1976), who reported that, in general, South African soils do not have $\mathrm{K}$ deficiency problems. Although the uptake of $\mathrm{Mg}$ did not respond to manure and fertiliser application, its residual levels increased at manure rates of 5 and $10 \mathrm{t} / \mathrm{ha}$ (Table 6). Calcium ranged between 3914 and $4690 \mathrm{mg} \mathrm{Ca} / \mathrm{kg}$. The manure rate of $10 \mathrm{t} /$ ha gave a significantly higher calcium level than all the other treatments (Table 6). Low manure rates ( 0.3 to $1.3 \mathrm{t} / \mathrm{ha}$ ) did not increase residual $\mathrm{Zn}$ levels significantly above the unfertilised control, while higher manure applica- 


\begin{tabular}{|c|c|c|c|c|c|c|c|c|}
\hline \multicolumn{9}{|c|}{$\begin{array}{c}\text { TABLE } 6 \\
\text { Effects of sheep kraal manure application rates on residual soil nutrient composition }\end{array}$} \\
\hline \multirow{2}{*}{$\begin{array}{l}\text { Manure rate } \\
\text { (t/ha) }\end{array}$} & \multirow{2}{*}{$\mathrm{pH}(\mathrm{KCl})$} & \multirow{2}{*}{$\begin{array}{c}\text { Total N } \\
(\%)\end{array}$} & \multirow[t]{2}{*}{ OC (\%) } & \multicolumn{5}{|c|}{ Selected nutrients $(\mathrm{mg} / \mathrm{kg})$} \\
\hline & & & & $\mathbf{P}$ & $\mathrm{K}$ & Mg & $\mathrm{Ca}$ & $Z \mathbf{n}$ \\
\hline 0 & $5.40 \mathrm{c}$ & 0.07 & $1.70 \mathrm{~b}$ & $4.00 \mathrm{~d}$ & $212.00 \mathrm{~d}$ & $309.70 c$ & $3914 b$ & $1.61 \mathrm{e}$ \\
\hline 0.3 & $5.50 c$ & 0.09 & $1.93 a$ & $4.50 \mathrm{~d}$ & 203.28d & $325.63 b c$ & $3943 b$ & 2.13cde \\
\hline 0.6 & $5.45 c$ & 0.09 & 1.74ab & 4.87d & $237.55 d$ & 344.83bc & 3900b & 1.88de \\
\hline 1.3 & $5.50 c$ & 0.10 & 1.88ab & $6.21 \mathrm{~d}$ & $268.75 d$ & 359.75bc & $3822 b$ & $2.02 \mathrm{cde}$ \\
\hline 2.5 & $5.55 \mathrm{bc}$ & 0.10 & 1.89ab & $15.28 \mathrm{c}$ & $351.75 c$ & $350.50 \mathrm{bc}$ & $4038 \mathrm{~b}$ & $2.28 \mathrm{bcd}$ \\
\hline 5.0 & 5.70ab & 0.09 & $1.92 \mathrm{a}$ & $19.50 \mathrm{c}$ & 433.61b & $376.00 \mathrm{~b}$ & $4019 \mathrm{~b}$ & $2.43 \mathrm{bc}$ \\
\hline 10.0 & $5.80 a$ & 0.09 & $1.87 a b$ & $28.00 \mathrm{~b}$ & $533.75 a$ & $456.50 a$ & $4690 a$ & $2.78 \mathrm{~b}$ \\
\hline NPK fertiliser & $5.20 \mathrm{~d}$ & 0.09 & 1.78ab & $36.23 a$ & $267.25 d$ & $362.63 \mathrm{bc}$ & $3968 b$ & $6.04 a$ \\
\hline CV (\%) & 2.02 & 17.50 & 7.01 & 29.21 & 14.36 & 10.71 & 9.32 & 13.12 \\
\hline
\end{tabular}

*Means in each column followed by the same letter or none at all are not significantly different at $p<0.05$.

tions $(\geq 2.5 \mathrm{t} / \mathrm{ha}$ ) significantly increased soil $\mathrm{Zn}$ levels. This indicates that the application of sheep manure can increase the zinc fertility of $\mathrm{Zn}$ deficient soils. In the present study, however, Zn was not a problem as levels in all treatments, including the control were within or above the critical range of 1.5 to $2 \mathrm{mg}$ $\mathrm{Zn} / \mathrm{kg}$ (Bornman et al., 1989). The inorganic NPK \{2:3:4(30) $+0.5 \% \mathrm{Zn}\}$ fertiliser treatment gave the highest level of residual $\mathrm{Zn}$ (Table 6), because the fertiliser contained $\mathrm{Zn}$ in its formulation.

\section{Conclusions}

The findings of this study suggest that sheep kraal manure rates of $2.5 \mathrm{t} /$ ha or higher could result in Amaranthus growth, yield and nutrient uptake, similar to those of the recommended NPK $\{2: 3: 4(30)+0.5 \% \mathrm{Zn}\}$ fertiliser at $150 \mathrm{~kg} / \mathrm{ha}$ under dry-land conditions of the Central Region of the Eastern Cape. In fact, at the young growth stage at which Amaranthus is normally harvested, fairly moderate sheep kraal manure applications gave better results than commercial inorganic NPK fertiliser. In addition to improved growth, the crop was enriched with iron and crude protein, which are very important in human nutrition. Sheep manure, at rates $\geq 2.5 \mathrm{t} / \mathrm{ha}$, raised soil $\mathrm{pH}$ (liming effect) and had high residual fertility, as indicated by high levels of $P$, $\mathrm{K}, \mathrm{Mg}$ and $\mathrm{Zn}$ at harvest time. Therefore, Amaranthus needs not be fertilised with mineral fertilisers where sheep kraal manure or other forms of manure are available. Organoleptic tests and other proximate analyses are needed to establish whether or not the yield increase observed with manure addition was at the expense of the good taste and high crop quality of the vegetable. Further research replicated over many sites and incorporating a comparative cost analysis is needed to establish the cost effectiveness of using kraal manure as a source of nutrients for Amaranthus.

\section{Acknowledgements}

The authors would like to acknowledge the National Research Foundation (NRF) for funding the research under Grant No. NRF-GUN 2050687, the Eastern Cape Department of Agriculture for granting Mr S. Mhlontlo study leave, Ms M. Maphaha for providing Amaranthus seeds and advice on seedling establishment; technical staff in the Department of Agronomy, University of Fort Hare, for help with the field experiment, and the Döhne Research Institute for analysis of some soil and plant samples.

\section{References}

ALLEMANN J, VAN DEN HEEVER E and VILJOEN J (1996) Evaluation of Amaranthus as a possible vegetable crop. Appl. Plant Sci. 10 1-4.

APHANE J, CHADHA ML and OLUOCH MO (2003) Increasing the consumption of micronutrient-rich foods through production of indigenous foods. In: Proc. FAO-AVRDC International Workshop. 5-8 March 2002, Arusha, Tanzania. AVRDC-the World Vegetable Centre, Shanua, Taiwan: AVRDC Publication No. 03-561. 1-77.

BHAT RB and RUBULUZA T (2002) The biodiversity of traditional vegetables of the Transkei region in the Eastern Cape of South Africa. S. Afr. J. Bot. 68 94-99.

BORNMAN JJ, RANWELL JF, VENTER GCH and VOSLOO LB (eds.) (1989) FSSA Fertilizer Handbook. The Fertilizer Society of South Africa, Hennopsmeer, South Africa. 275 pp.

BRADY NC and WEIL RR (1999) The Nature and Properties of Soils. (12 ${ }^{\text {th }}$ edn.) Prentice-Hall, New Jersey. $881 \mathrm{pp}$.

EGHBALL B and Power JF (1999) Phosphorus and nitrogen based manure and compost application: Corn production and soil phosphorus. Soil Sci. Soc .Am. J. 63 895-901.

ELBEHRI A, PUTMAN DH and SCHMITT M (1993) Nitrogen fertilizer and cultivar effects on yield and nitrogen-use efficiency of grain amaranth. Agron. J. 85 120-128.

JANSEN VAN RENSBURG WS, VENTER SL, NETSHILUVHI TR, VAN DEN HEEVER E and DE RONDE JA (2004) Role of indigenous leafy vegetables in combating hunger and malnutrition. S. Afr. J. Bot. 70 52-59.

LAKER MC (1976) Soil fertility and the potential for increased crop production in the South African Homelands. Fert. Soc. S. Afr. J. 2 21-24.

MAKUS DJ (1984) Evaluation of Amaranth as a potential greens crop in the Mid-south. HortSci 19 881-883.

MANDIRINGANA OT, MNKENI PNS, MKILE Z, VAN AVERBEKE W, VAN RANST E and VERPLANCKE (2005) Mineralogy and fertility status of selected soils of the Eastern Cape Province, South Africa. Comm Soil Sci and Plant Anal 36 2431-2446.

OKALEBO JR, GATHUA KW and WOOMER PL (2002) Laboratory Methods of Soil and Water Analysis: A Working Manual ( $2^{\text {nd }}$ edn.) Nairobi, Kenya. SACRED Africa. 128 pp.

ORE-OLUWA AT, FETUGA BL and OYENUGA VA (1981) Accumulation of mineral elements in five tropical leafy vegetables as influenced by nitrogen fertilization and age. Sci. Hortic. 18 313-322.

SCHIPPERS RR (2000) African Indigenous Vegetables: An Overview of the Cultivated Species. Chatham, UK: Natural Resource Institute/ACP-EU Technical Centre for Agricultural Resources and Rural Cooperation. 511-516.

VAN AVERBEKE W and DE LANGE AO (1995) Agro-ecological conditions and land use. In: De Wet C and Van Averbeke W (eds.) Regional Overview of Land Reform-Related Issues in the Eastern Cape Province. Working paper 24 EC 2., LAPC, Johannesburg. 62 pp. 
VAN AVERBEKE W and YOGANATHAN S (1997) Using Kraal Manure as a Fertilizer. ARDRI, Fort Hare and the National Department of Agriculture, Resource Centre, Directorate Communication. Government Printer, Pretoria, SA. 19 pp.
WEHMEYER AS and ROSE EF (1983) Important indigenous plants in the Transkei as food supplements. Bothalia 14 613-615. 